\title{
HUBUNGAN MAKANAN DAN MINUMAN YANG BERSIFAT IRITAN DENGAN KEJADIAN GASTRITIS DI DESA PENYESAWAN WILAYAH KERJA PUSKESMAS KAMPAR
}

\author{
Ade Dita Puteri ${ }^{1}$ \\ S1 Kesehatan Masyarakat Universitas Pahlawan Tuanku Tambusai \\ adedita10@gmail.com
}

\begin{abstract}
The irritans food and drinks are very influential on the incidence of gastritis. Gastritis is the most common disorder encountered in the clinic because it is diagnosed based solely on clinical symptoms. This situation is caused by food and drink irritating the gastric mucosa, excessive gastric mucosa secretions by the stomach's own secretions and sometimes due to bacterial inflammation. The purpose of this study was to determine the relationship between food and drink irritants with the incidence of gastritis in the Penyesawan Village, the working area of the Puskesmas Kampar in 2021. The design of this study used an analytical research design with a cross-sectional design. The sample in this study were is the KK of 229 people in the village of Penyesawan in the working area of the Puskesmas Kampar. The sampling technique was simple random sampling. The research instrument used a questionnaire and data processing was carried out univariate and bivariate. The research relevealed on statistical tests, it was found that X2 $=10.861$ with $P$ value $=0.002(p<0.005)$, which means that there is a significant relationship between food irritants and the incidence of gastritis. $X 2=8,222$ with $P$ value $=0,006$ ( $p<0,005)$, which means that there is a relationship between irritant drinks and the incidence of gastritis. It is expected to the management of the health program will increase counseling and provision of health information about diet and types of food that must be avoided to prevent gastritis.
\end{abstract}

Keywords $\quad$ : Food and Beverages are Irritant, Gastritis

\begin{abstract}
ABSTRAK
Makanan dan minuman yang bersifat iritan sangat berpengaruh terhadap kejadian gastritis. Gastritis merupakan gangguan yang paling sering ditemui diklinik karena didiagnosisnya hanya berdasarkan gejala klinis. Keadaaan ini dapat diakibatkan dari makanan dan minuman yang mengiritasi mukosa lambung, pengeluaran mukosa lambung yang berlebihan oleh secret lambung sendiri dan kadangkadang karena peradangan bakteri. Tujuan penelitian ini adalah untuk mengetahui hubungan makanan dan minuman yang bersifat iritan dengan kejadian gastritis di Desa Penyesawan Wilayah Kerja Puskesmas Kampar tahun 2021. Desain penelitian ini menggunakan desain penelitian analitik dengan rancangan crossectional. Sampel pada penelitian ini adalah KK yang ada di Desa Penyesawan Wilayah Kerja Puskesmas Kampar yang berjumlah 229 orang. Teknik pengambilan sampel adalah simple random sampling. Instrument penelitian ini menggunakan kuesioner dan pengolahan data dilakukan secara univariat dan bivariat. Hasil penelitian Berdasarkan uji statistik diperoleh bahwa $\mathrm{X}^{2}$ $=10,861$ dengan $\mathrm{P}$ value $=0,002(\mathrm{p}<0,005)$ yang berarti ada hubungan yang bermakna antara makanan bersifat iritan dengan kejadian gastritis. $X^{2}=8,222$ dengan $P$ value $=0,006(p<0,005)$ yang berarti ada hubungan minuman bersifat iritan dengan kejadian gastritis. Diharapkan kepada bagian pengelola program kesehatan agar meningkatkan penyuluhan-penyuluhan dan pemberian informasi kesehatan tentang pola makan dan jenis makanan yang harus dihindari untuk mencegah gastritis.
\end{abstract}

Kata Kunci : Makanan dan Minuman Bersifat Iritan, Gastritis

PENDAHULUAN

Pembangunan nasional bertujuan untuk meningkatkan kualitas sumber daya manusia yang dilakukan secara berkelanjutan. Menurut Notoadmodjo (2010), Berdasarkan visi pembangunan kesehatan Indonesia seperti yang 
tercantum dalam Undang -Undang Kesehatan RI No 36 tahun 2009, yakni: meningkatkan kesadaran, kemauan dan kemampuan hidup sehat bagi setiap orang agar terwujud derajat kesehatan masyarakat yang setinggi-tingginya, sebagai investasi sumber daya manusia yang produktif secara sosial ekonomi. Masalah kesehatan masyarakat, termasuk penyakit ditentukan oleh dua faktor utama yaitu faktor perilaku dan non perilaku, oleh sebab itu upaya penanggulangan masyarakat juga dapat ditujukan pada kedua faktor utama tersebut.

Tingkat kesadaran masyarakat Indonesia masih sangat rendah mengenai pentingnya menjaga kesehatan lambung, padahal gastritis atau sakit maag akan sangat mengganggu aktivitas sehari-hari, baik bagi remaja maupun orang dewasa. Gastritis atau dikenal dengan sakit maag merupakan peradangan (pembengkakan) dari mukosa lambung yang disebabkan oleh faktor iritasi dan infeksi. Bahaya penyakit gastritis jika dibiarkan terus menerusakan merusak fungsi lambung dan dapat meningkatkan risiko untuk terkena kanker lambung hingga menyebabkan kematian. Berbagai penelitian menyimpulkan bahwa keluhan sakit pada penyakit gastritis paling banyak ditemui akibat dari gastritis fungsional, yaitu mencapai $70-80 \%$ dari seluruh kasus. Gastritis fungsional merupakan sakit yang bukan disebabkan oleh gangguan pada organ lambung melainkan lebih sering dipicu oleh pola makan yang kurang sesuai, faktor psikis dan kecemasan (Saydam, 2011).

Gastritis atau yang secara umum dikenal dengan istilah sakit "maag" atau sakit ulu hati ialah peradangan pada dinding lambung terutama pada selaput lendir lambung. Gastritis merupakan gangguan yang paling sering ditemui karena didiagnosisnya hanya berdasarkan gejala klinis. Keadaaan ini dapat diakibatkan dari makanan yang mengiritasi mukosa lambung, pengeluaran mukosa lambung yang berlebihan oleh secret lambung sendiri dan kadang-kadang karena peradangan bakteri. Kondisi lainnya yang sering menimbulkan gastritis adalah iritasi atau penipisan selaput lambung akibat konsumsi minuman beralkohol (Kristanti H, 2013).

Penyakit ini sering timbul secara mendadak yang biasanya ditandai dengan rasa mual dan muntah, perdarahan, rasa lelah, nafsu makan menurun, atau sakit kepala. Hal ini dapat disebabkan karena kebiasaan mengonsumsi suatu jenis makanan yang sensitif bagi orang tersebut, makan terlalu cepat, atau makan dengan gangguan emosional. Kondisi yang timbul mendadak atau sakit maag (akut) umumnya berlangsung singkat. Selain itu penyakit ini kadang timbul secara menahun (kronis), dimana penyebabnya tidak diketahui dengan jelas. Penyakit gastritis yang kronis dapat dimulai dengan adanya infeksi suatu bakteri yang disebut dengan Helicobacter pylori, sehingga menggangu pertahanan dinding mukosa (Kristanti H, 2013). Menurut Price dalam Sari (2017) makanan dan minuman yang bersifat iritan yaitu makanan yang sifatnya berbumbu dan minuman dengan kandungan kafein dan alcohol merupakan agen-agen penyebab iritasi mukosa lambung.

Badan organisasi kesehatan dunia WHO (2010), mengadakan tinjauan terhadap delapan Negara dunia dan mendapatkan beberapa hasil presentase angka kejadian gastritis di dunia, dimulai dari Negara yang kejadian gastritisnya paling tinggi yaitu Amerika dengan presentase mencapai $47 \%$ kemudian di ikuti oleh India dengan presentase mencapai $43 \%$, lalu dibeberapa Negara lainnya seperti Inggris $22 \%$, China $31 \%$,Jepang $14,5 \%$,Kanada 35\%,Perancis $29,5 \%$ dan Indonesia 41\%. Hasil penelitian dan pengamatan yang dilakukan oleh Departemen Kesehatan RI angka kejadian gastritis di beberapa kota di Indonesia sangat tinggi mencapai $91,6 \%$ yakni di kota Medan, lalu di beberapa kota lainnya seperti Surabaya 31,2\%, Denpasar 46\%, 
Jakarta 50\%, Bandung 32,5\%, Palembang $35,35 \%$, Aceh $31,7 \%$ dan Pontianak $31,2 \%$. Hal tersebut disebabkan oleh pola makan yang kurang sehat. Tahun 2019 penyakit gastritis merupakan salah satu penyakit yang termasuk ke dalam sepuluh penyakit terbanyak pada pasien rawat inap di rumah sakit seluruh Indonesia dan menyerang lebih banyak perempuan dari pada laki-laki dengan jumlah kasus 30.154 orang (Profil Kesehatan Indonesia, 2019).

Penyakit gastritis termasuk kedalam sepuluh penyakit terbanyak di Provinsi Riau setiap tahun, pada tahun 2019 tercatat jumlah penderita penyakit gastritis sebanyak 6,52\% (Profil Kesehatan Riau, 2019). Berdasarkan data dari bulan januari - desember 2019 terdapat jumlah penderita gastritis sebanyak 125 penderita. sedangkan pada bulan januari - juni 2020 terdapat jumlah penderita gastritis di desa penyesawan sebanyak 80 penderita. Hal ini membuktikan bahwa adanya peningkatan penyakit gastritis dari tahun 2019-2020. Berdasarkan survey awal yang dilakukan di desa penyesawan bahwa dari 10 responden terdapat 8 responden yang berumur dari 25-64 tahun, makanan yang dikonsumsi responden sering mengandung makanan yang bersifat iritan, salah satunya yaitu seperti sayuran kol, sawi dan dari 10 orang responden 2 orang responden selalu mengkonsumsi minuman yang mengandung gas seperti minuman kaleng sprit dan minuman kopi. Tujuan penelitian ini yakni untuk mengetahui apakah ada hubungan makanan dan minuman yang bersifat iritan dengan kejadian gastritis di Desa Naga Beralih Wilayah Kerja Puskesmas Kampar Utara.

\section{METODE}

Penelitian ini menggunakan desain penelitian analitik dengan rancangan crossectional. Penelitian ini dilakukan pada tanggal 22 - 27 Februari 2021, dengan jumlah responden sebanyak 229 Kepala Keluarga yang tinggal di desa Penyesawan Wilayah Kerja Puskesmas
Kampar. Teknik pengambilan sampel pada penelitian ini adalah Simple Random Sampling, yaitu pengambilan sampel yang dilakukan secara acak di Desa Penyesawan. Berdasarkan rumus besar sampel tersebut, diperoleh jumlah sampel 229 orang. Instrumen yang digunakan dalam pengumpulan data adalah kuesioner yang berisikan sejumlah pertanyaan yang berhubungan dengan makanan dan minuman yang bersifat iritan dengan kejadian gastritis. Analisa data yang digunakan adalah analisa univariat dan analisa bivariate.

\section{HASIL}

\section{Analisa Univariat}

Tabel 1. Distribusi Frekuensi Umur

\begin{tabular}{rrrr}
\hline No & Umur & Frekuensi & Persentase \%) \\
\hline 1 & $25-44$ & 95 & 41 \\
$\mathbf{2}$ & $\mathbf{4 5 - 6 4}$ & $\mathbf{1 3 4}$ & $\mathbf{5 9}$ \\
\hline & Total & $\mathbf{2 2 9}$ & $\mathbf{1 0 0}$ \\
\hline
\end{tabular}

Dari tabel 1 diatas dapat diketahui bahwa dari 229 responden, 134 responden (59\%) berada pada kategori umur 45-64 tahun dan 95 responden $(41 \%)$ berada pada kategori umur 2544 tahun.

Tabel 2. Distribusi Frekuensi Jenis Kelamin

No Jenis Kelamin rekuensi 'ersentase (\%)

\begin{tabular}{rrrr}
\hline 1 & Perempuan & 56 & 24,4 \\
$\mathbf{2}$ & Laki-Laki & $\mathbf{1 7 3}$ & $\mathbf{7 5 , 6}$ \\
\hline & Total & $\mathbf{2 2 9}$ & $\mathbf{1 0 0}$ \\
\hline
\end{tabular}

Dari tabel 2 diatas dapat diketahui bahwa 173 responden $(75,6 \%)$ berjenis kelamin laki-laki dan 56 responden $(24,4 \%)$ berjenis kelamin perempuan.

Tabel 3. Distribusi Frekuensi Pekerjaan

\begin{tabular}{cccc}
\hline No & Pekerjaan & Frekuensi & $\begin{array}{c}\text { Persentase } \\
(\boldsymbol{\%})\end{array}$ \\
\hline 1 & Pengrajin & 17 & 19 \\
$\mathbf{2}$ & Petani & $\mathbf{4 6}$ & $\mathbf{5 2}$ \\
3 & Pedagang & 21 & 24 \\
4 & PNS & 4 & 5 \\
\hline & Total & $\mathbf{8 8}$ & $\mathbf{1 0 0}$ \\
\hline
\end{tabular}


Dari tabel 3 dapat diketahui bahwa pekerjaan responden yang terbanyak adalah kategori pekerjaan petani dengan jumlah 46 responden (52\%) dan dari tabel 4 dapat diketahui bahwa sebagian besar responden tidak pernah menderita gastritis yaitu sebanyak 149 responden $(65 \%)$.
Tabel 4. Distribusi Frekuensi Kejadian Gastritis

\begin{tabular}{cccc}
\hline No & $\begin{array}{c}\text { Kejadian } \\
\text { Gastritis }\end{array}$ & Frekuensi & $\begin{array}{c}\text { Persentase } \\
(\%)\end{array}$ \\
\hline 1 & $\begin{array}{c}\text { Pernah } \\
\text { Gastritis }\end{array}$ & 80 & 35 \\
Tidak & & \\
$\mathbf{P}$ & $\begin{array}{c}\text { Pernah } \\
\text { Gastritis }\end{array}$ & $\mathbf{1 4 9}$ & $\mathbf{6 5}$ \\
\hline & Total & $\mathbf{2 2 9}$ & $\mathbf{1 0 0}$ \\
\hline
\end{tabular}

\section{Analisa Bivariat}

Tabel 5. Hubungan Makanan Penyebab Iritan dengan Kejadian Gastritis

\begin{tabular}{|c|c|c|c|c|c|c|c|c|}
\hline \multirow{3}{*}{$\begin{array}{c}\text { Makanan Penyebab } \\
\text { Iritan }\end{array}$} & \multicolumn{4}{|c|}{ Kejadian Gastritis } & \multirow{2}{*}{\multicolumn{2}{|c|}{ Total }} & \multirow{3}{*}{$\mathbf{X}^{2}$} & \multirow{3}{*}{$\mathbf{P}$} \\
\hline & \multicolumn{2}{|c|}{$\begin{array}{l}\text { Pernah } \\
\text { gastritis }\end{array}$} & \multicolumn{2}{|c|}{$\begin{array}{l}\text { Tidak pernah } \\
\text { gastritis }\end{array}$} & & & & \\
\hline & n & $\%$ & $\mathbf{N}$ & $\%$ & $\mathbf{n}$ & $\%$ & & \\
\hline$>3$ kali seminggu & 46 & 46,9 & 52 & 53,1 & 98 & 100 & & \\
\hline$<3$ kali seminggu & 34 & 26,0 & 97 & 74,0 & 131 & 100 & 10,861 & 0,002 \\
\hline Total & 80 & 72,9 & 149 & 127,1 & 229 & 100 & & \\
\hline
\end{tabular}

Dari tabel 5 diatas diketahui bahwa mengkonsumsi makanan penyebab iritan < 3 kali seminggu menyebabkan 34 responden $(26 \%)$ pernah menderita gastritis dan 97 responden $(74 \% \%)$ tidak pernah menderita gastritis.
Berdasarkan uji statistik diperoleh bahwa $\mathbf{X}^{\mathbf{2}}=10,861$ dengan $\mathrm{P}$ value $=0,002$ $(\mathrm{p}<0,005)$ yang berarti hipotesis gagal ditolak dan ada hubungan yang bermakna antara makanan penyebab iritan dengan kejadian gastritis.

Tabel. 6 Hubungan Minuman Penyebab Iritan dengan Kejadian Gastritis

\begin{tabular}{|c|c|c|c|c|c|c|c|c|}
\hline \multirow{3}{*}{$\begin{array}{c}\text { Minuman Penyebab } \\
\text { Iritan }\end{array}$} & \multicolumn{4}{|c|}{ Kejadian Gastritis } & \multirow{2}{*}{\multicolumn{2}{|c|}{ Total }} & \multirow{3}{*}{$\mathbf{X}^{2}$} & \multirow{3}{*}{$\mathbf{P}$} \\
\hline & \multicolumn{2}{|c|}{$\begin{array}{l}\text { Pernah } \\
\text { gastritis }\end{array}$} & \multicolumn{2}{|c|}{$\begin{array}{l}\text { Tidak pernah } \\
\text { gastritis }\end{array}$} & & & & \\
\hline & n & $\%$ & $\mathbf{n}$ & $\%$ & $\mathbf{n}$ & $\%$ & & \\
\hline$>3$ kali seminggu & 56 & 42,7 & 75 & 57,3 & 131 & 100 & & \\
\hline$<3$ kali seminggu & 24 & 24,5 & 74 & 75,5 & 98 & 100 & 8,222 & 0,006 \\
\hline Total & 80 & 67,2 & 149 & 132,8 & 229 & 100 & & \\
\hline
\end{tabular}

Dari tabel 4.6 diatas diketahui bahwa mengkonsumsi minuman penyebab iritan menyebabkan 56 responden $(42,7 \%)$ pernah menderita gastritis dan 75 responden $(57,3 \%)$ tidak pernah menderita gastritis.. Berdasarkan uji statistik diperoleh bahwa $\mathrm{X}^{2}=8,222$ dengan $\mathrm{P}$ value $=0,006(p<0,005)$ yang berarti hipotesis gagal diterima dan ada hubungan yang bermakna antara minuman penyebab iritan dengan kejadian gastritis.

\section{PEMBAHASAN}

Hubungan Makanan Penyebab Iritan dengan Kejadian Gastritis di Desa Penyesawan Wilayah Kerja Puskesmas Kampar

Berdasarkan uji statistik diperoleh bahwa $X^{2}=10,861$ dengan $P$ value $=0,002$ $(p<0,005)$ yang berarti hipotesis gagal diterima dan ada hubungan yang bermakna 
antara makanan penyebab iritan dengan kejadian gastritis. Menurut asumsi peneliti mengapa masih ada responden yang menderita gastritis sedangkan mereka mengkonsumsi makanan penyebab iritan < 3 kali seminggu, dikarenakan ada faktor lain yang menyebabkan gastritis seperti pola makan yang tidak teratur, stress dan lain sebagainya.

Gastritis biasanya diawali oleh pola makan yang tidak teratur. Kebiasaan makan yang buruk dan mengkomsumsi makanan yang tidak hygiene merupakan faktor resiko terjadinya gastritis (Wahyu, 2011). Menurut Yuliarti dalam Hartati (2014) Gastritis terjadi karna ketidaksesuaian lambung dengan makanan yang dimakan seperti makanan yang pedas (cabai atau merica) atau makanan yang memiliki kadar lemak tinggi, dan makanan yang bersifat asam sehingga produksi asam lambung tidak terkontrol. Menurut Oktavia dalam Anggita (2012), mengkonsumsi makanan pedas secara berlebihan akan merangsang system pencernaan, terutama lambung dan usus yang berkontraksi. Hal ini akan menyebabkan rasa panas dan nyeri di ulu hati yang disertai mual dan muntah. Bila kebiasaan mengkonsumsi makanan lebih dari satu kali dalam seminggu selama minimal enam bulan dibiarkan terus menerus dapat menyebabkan iritasi pada lambung yang dosebut dengan gastritis. Selanjutnya, makanan asam juga dapat menyebabkan gastritis. Asam dapat memperlambat pengosongan lambung. Sebelum memasuki duodenum, kimus yang bersifat asam akan dinetralisasi oleh natrium bikarbonat $\left(\mathrm{NaHCO}_{3}\right)$. Jika proses netralisasi belum selesai maka kimus asam akan berada di dalam lambung. Proses ini tentu akan semakin mengiritasi lapisan mukosa lambung dan menimbulkan serangan gastritis (Anggita, 2012)

Hal ini senada dengan penelitian yang dilakukan Mawey (2014), signifikan antara konsumsi makan makanan pedas dan konsumsi makan makanan bersifat asam terhadap kejadian gastritis. Hal yang sama juga dikemukan oleh Tussakinah, (2017) yang mengatakan bahwa terdapat hubungan antara pola makan dengan kejadian gastritis.

\section{Hubungan Minuman Penyebab Iritan dengan Kejadian Gastritis di Desa Penyesawan Wilayah Kerja Puskesmas Kampar Tahun 2021.}

Dari hasil penelitian diketahui bahwa mengkonsumsi minuman penyebab iritan $>3$ kali seminggu menyebabkan 56 responden $(42,7 \%)$ pernah menderita gastritis dan 75 responden $(57,3 \%)$ tidak pernah menderita gastritis. Menurut asumsi peneliti bahwa gastritis tidak hanya dapat dipicu dari berbagai faktor resiko ( konsumsi alkohol yang terlalu banyak, rokok, kafein, kopi dan teh ) namun juga dapat dipicu oleh kondisi kejiwaan seseorang dimana tingkat stres seseorang dapat meningkatkan produksi asam lambung yang dapat mengakibatkan terjadinya gastritis. Berdasarkan uji statistik diperoleh bahwa $\mathbf{X}^{\mathbf{2}}=8,222$ dengan $P$ value $=0,006(p<0,005)$ yang berarti hipotesis gagal diterima dan ada hubungan yang bermakna antara minuman penyebab iritan dengan kejadian gastritis.

Menurut Yunita dalam Derry (2020), alkohol bekerja melenturkan Katup LES, sehingga menyebabkan refluks atau berbaliknya asam lambung ke kerongkongan, sehingga menyebabkan gas di lambung naik hingga ke kerongkongan. Selain alcohol, minum teh, kopi atau minuman lain yang mengandung kafein dapat mengendurkan Lower Esophageal Spincther (LES), katup antara lambung dan tenggorokan, sehingga menyebabkan gas di lambung naik hingga kerongkongan. Menurut Oktavia dalam Anggita (2012) kafein dapat menyebabkan stimulasi system saraf pusat sehingga dapat meningkatkan aktifitas lambung dan sekresi hormon gastrin pada lambung dan pepsin. Hormon gastrin yang dikeluarkan oleh lambung mempunyai efek sekresi getah lambung yang sangat asam dari bagian fundus lambung. Hal ini sejalan 
dengan yang diungkapkan oleh Guyton dalam Dewi (2017) kafein adalah salah satu dari zat sekretagogue yang merupakan salah satu penyebab antrum mukosa lambung menyekresikan hormon gastrin. Sherwood dalam Anggita (2012) menambahkan bahwa kafein dapat merangsang sekresi getah lambung yang sangat asam walaupun tidak ada makanan. Kafein juga dapat menstimulasi produksi pepsin yang bersifat asam sehingga dapat menyebabkan iritasi dan erosi mukosa lambung.

Minuman bersoda juga mengandung kafein. Dan seperti yang telah disampaikan sebelumnya bahwa kafein dapat memicu sekresi getah lambung yang sangat asam lebih dari yang dibutuhkan meskipun tidak ada makanan didalam lambung. Minuman bersoda juga memiliki $\mathrm{pH}$ antara 3-4, artinya bersifat asam. Dan seperti yang dijelaskan sebelumnya bahwa asam dapat memperlambat pengosongan lambung sebelum dinetralisir masuk ke duodenum. Asam yang tertahan lama dilambung akan meningkatkan peluang lapisan mukosa lambung untuk teriritasi (Anonim, 2011). Hal ini sesuai dengan penelitian Wahyudi, dkk (2018) yang menyatakan bahwa frekuensi minum minuman iritatif seperti kopi, soda dan alcohol berpengaruh signifikan terhadap kejadian gastritis.

\section{KESIMPULAN}

Dari hasil penelitian dapat disimpulkan bahwa ada hubungan yang bermakna antara makanan dan minuman yang bersifat iritan dengan kejadian gastritis Desa Penyesawan Wilayah Kerja Puskesmas Kampar Tahun 2021

\section{UCAPAN TERIMA KASIH}

Penelitian ini dapat terlaksana dengan lancar atas partisipasi dari berbagai pihak. Untuk itu tim penelitian mengucapkan terima kasih kepada pihak-pihak berikut:
Lembaga Penelitian dan Pengabdian pada Masyarakat (LPPM) Universitas Pahlawan Tuanku Tambusai yang telah memfasilitasi penelitian dan Semua pihak yang ikut membantu kelancaran penelitian ini.

\section{DAFTAR PUSTAKA}

Anggita, N, (2012). Hubungan Faktor Konsumsi dan Karakteristik Individu dengan Persepsi Gangguan Lambung pada Mahasiswa. http://lontar.ui.ac.id.

Anonim, (2011). Penyakit Gastritis Akut. http://www.scribd.com/doc.

Blecenda M, dkk, (2009). Makanan Penyembuh Ajaib. Cetakan ke-6, Jakarta, Indonesia Publishing House

DinKes PropRiau, (2011). Profil Kesehatan Propinsi Riau.

DinKes KabKap, (2021). Profil kesehatan kabupaten kampar.

Guyton, A.C, (2001). Buku Ajar Fisiologi Kedokteran. Jakarta: Penerbit Buku Kedokteran EGC Jakarta.

Hidayat, A. A (2008). Metode Penelitian Keperawatan dan Teknik Analisa Data. Jakarta, Salemba Medika.

Kristanti Handriani, (2013). Menjegah \& mengobati 11 Penyakit Kronis. Jakarta, Citra Pustaka

Muttaqin Arif \& Sari Kumala, (2011).Gangguan Gastrointestinal. Jakarta, Salemba Medika.

Mansyoer Arif, dkk. (2001). Kapita Selekta Kedokteran. Edisi 3, Cetakan ke-3, jakarta, Media Aesculapius

Notoatmodjo S, (2007). Metodologi Penelitian Kesehatan. Jakarta, Rineka Cipta.

Notoatmodjo S, (2010). Metodologi Penelitian Kesehatan. Cetakan ke3, Jakarta, Reneka Cipta.

Nursalam, (2013). Metodologi Penelitian Ilmu Keperawatan. Edisi 3, Jakarta, Salemba Medika. 
Oktovia, Wati. (2009). Hubungan Pola Makan Dengan Gastritis Pada Mahasiswa S1 Keperawatan Program A FIKES UPN Veteran Jakarta Tahun 2011. http://www.library.upnvj.ac.id.

Puskesmas Kampar, (2021). Profil Kesehatan Wilayah Puskesmas Kampar.

Puteri, A. D., \& Sudirman, S. (2017). The Influence Of Traditional Food on Incidience of Stroke in Banda Aceh. Journal of Healthcare Technology and Medicine, 1(2).

Sherwood, Laura Lee, (2001). Fisiologi Manusia: dari Sel ke Sistem ed.2. Jakarta: Penerbit Buku Kedokteran EGC.
Smeltzer, Suzanne C, (2003). Buku Ajar Keperawatan Medikal Bedah. Edisi 8, Vol 3, Jakarta EGC

STIKes.T.T, (2021). Panduan Penulisan Karya Tulis Imiah Mahasiswa.

Wahyu, A, (2011). Maag dan Gangguan Pencernaan. Jakarta: PT Sunda Kelapa Pustaka.

Yuliarti Nurheti, (2009). Maag: Kenali, Hindari, dan Obat. Yogyakarta, CV ANDI OFFSET.

Yunita, R, (2010). Hubungan Antara Karakteristik Responden, Kebiasaan Makan dan Minum Serta Pemakaian NSAID dengan Terjadinya Gastritis. http://adln.fkm.unair.ac.id. 